Journal of Applied Pharmaceutical Science Vol. 7 (10), pp. 144-151, October, 2017

Available online at http://www.japsonline.com

DOI: $10.7324 / \mathrm{JAPS} .2017 .71021$

ISSN 2231-3354 (c) BY-NC-SA

\title{
Chemical composition and biological activities of methanol extract from Macrocybe lobayensis
}

\author{
Somanjana Khatua, Sandipta Ghosh, Krishnendu Acharya* \\ Molecular and Applied Mycology and Plant Pathology Laboratory, Department of Botany, Centre of Advanced Study, University of Calcutta, 35, \\ Ballygunge Circular Road, Kolkata, 700019, West Bengal, India.
}

\section{ARTICLE INFO \\ Article history: \\ Received on: 30/07/2017 \\ Accepted on: 08/09/2017 \\ Available online: 30/10/2017}

\section{Key words:}

Phenolic constituents,

Antioxidant activity,

Antibacterial property,

Cytotoxic effect, HPLC,

Folk edible mushroom.

\begin{abstract}
Over the generations, Macrocybe lobayensis has become an integral part of tribal cuisines of India particularly for its aroma and taste. However, no investigation has been carried out so far on its secondary metabolites that may account for therapeutic potential. Therefore, aim of the present study was to identify major constituents of methanol extract isolated from the wild mushroom and examine spectrum of pharmacological activities. Chemical characterization by spectrophotometer and HPLC depicted that the fraction was mainly consisted of phenolic compounds ( $p$-hydroxybenzoic acid $<p$-coumaric acid < cinnamic acid < salicylic acid< pyrogallol); while ascorbic acid and carotenoids were detected in lesser extent. In terms of screening medicinal prospects, the extract presented strong radical scavenging activity ( $\mathrm{DPPH}$ and $\mathrm{ABTS}^{+}$), chelating ability of ferrous ion, reducing power and total antioxidant capacity. The methanol formulation also exhibited antibacterial properties against both Gram-positive and Gram-negative strains, with MIC values ranging from 245.13-1585.81 $\mu \mathrm{g} / \mathrm{ml}$. Finally, Hep3B human liver carcinoma cells were challenged with the extract to assess cytotoxic effect and result showed concentration dependent decrease in cell viability $\left(\mathrm{IC}_{50}\right.$ of $234.31 \mu \mathrm{g} / \mathrm{ml}$ ). Overall, features described in this work provides the first attempt to establish medicinal prospects of phenolic compounds from M. lobayensis empowering its use in pharmaceutical industry.
\end{abstract}

\section{INTRODUCTION}

Free radicals can be defined as any unstable and highly reactive molecular species that contain an unpaired electron in their atomic orbital. They are derived inside human body either through normal metabolic processes or from exogenous sources like air pollutants, $\mathrm{X}$-rays, cigarette smoke, ozone and industrial chemicals (Khatua et al., 2013). Generally, these compounds are beneficiary to us when present in low or moderate level as they play an important role in ion transportation, destruction of invading pathogens and apoptotic cell signalling (Lü et al., 2010). In contrary, when produced in excess quantity, free

\footnotetext{
* Corresponding Author

Krishnendu Acharya, Molecular and Applied Mycology and Plant Pathology Laboratory, Department of Botany, Centre of Advanced Study, University of Calcutta, 35, Ballygunge Circular Road, Kolkata, 700019, West Bengal, India. E-mail: krish_paper @ yahoo.com
}

radicals attack molecular components of cell responsible for pathogenesis of a large number of diseases (Valko et al., 2007). Consequently, the human body consists of an antioxidant defence system to protect against harmful effects of radicals. Nevertheless, substantial evidence indicated that ample intake of dietary antioxidants in form of foods or nutrients may help to maintain the antioxidant status inside human body (Alam et al., 2013).

Besides, continual growing emergence of antibiotic unaffected bacterial strains is another major threat to human health (Balouiri et al., 2016). It has been estimated that disseminate and indiscriminate use of antibiotics is the main cause of evolvement of drug resistant bacteria, while consequence of acquired mutation assisting bacterial survival also contributes to non-susceptibility of microorganisms. As a result, the prevalence and incidence of opportunistic infections are increasing significantly not only in hospitalised patients, but also in general population (Shen et al., 2017). Thus, treatment with appropriate therapeutic reagent is the sole way to minimise development of drug resistant strains and control infections (Ren et al., 2014). 
Else, continuous exposure of infectious pathogens stimulates the body defence system to generate excess amount of superoxide radical and nitric oxide through a process called inflammation. Repeated inflammatory signalling damages DNA in hepatocytes of regenerating liver and increases chance of gene mutation related to carcinogenesis. Currently the most common type of liver cancer is hepatocellular carcinoma which is one of the fore most prevalent malignancies in Asia, Europe and Africa. Treatment dealing with the disease is very limited due to nonresponsiveness to chemotherapy and radiotherapy (Shiraha et al., 2013). In this background, daily intake of anti-carcinogenic food is considered as the most effective mean for preventing cancer in human. Thus, edible anti-mutagenic compounds obtained from nature is of particular importance as it does not produce any xenobiotic effects on living organisms (Burcu et al., 2014).

Consequently, mushrooms have always been appreciated as nutraceutical food across the globe due to their immense role in prevention of various disorders (Valverde et al., 2015). They accumulate a variety of secondary metabolites, such as phenols, polyketides, steroids and terpenes. Among them, phenolics are one of the major group of dietary components that have proved to be associated with antioxidant (Acharya et al., 2015a, Acharya et al., 2015b, Acharya et al., 2016, Acharya et al., 2017a, Acharya et al., 2017b), antimicrobial (Khatua et al., 2015) and anticancer abilities (Yaltirak et al., 2009). Thus, researchers are showing increasing interest to investigate biological activities of macrofungi in order to discover novel therapeutic agent. Findings suggest that 158 species belonging to 88 genera have been recognized so far as new antibiotic sources effective against pathogenic microorganisms (Shen et al., 2017).

Conversely, more than 650 members of higher basidiomycetes have been identified till date that may have potential against various types of cancers (Liu et al., 2013). Besides, a large number of literature also provides extensive data on antioxidant activity of different wild edible mushrooms (Khatua et al., 2013, Mitra et al., 2013, Saha et al., 2013, Nandi et al., 2014, Samanta et al., 2015).

Macrocybe lobayensis (R. Heim) Pegler \& Lodge could be one of those matrices by providing a variety of biomolecules including phenolic compounds with diverse pharmacological properties. The species was discovered by French mycologist, Heim, in 1969 and originally described from Central African Republic as Tricholoma lobayense. In 1998, Pegler and Lodge created the genus, Macrocybe, depending upon several morphological characters to accommodate Tricholoma lobayensis. The species could be easily recognized in field owing to its pure white large basidiomes with strong cyanic smell. It is commonly known as Doodh Chhatu (Doodh means milk and Chhatu means mushroom) in West Bengal, India and consumed by several indigenous tribes. The mushroom has also been reported from Uttaranchal and Kerala of India where they have long been accepted as a popular food (Vrinda and Pradeep 2006). However, there is still no systematic investigation on medicinal prospect as well as mycochemical composition from the macrofungus except the study published by Liu et al. (1996) exhibiting immunemodulation and antitumor activity of polysaccharideprotein complex isolated from culture filtrate. In this backdrop, present work was carried out for the first time to provide basic information on bioactive phenolic compounds of methanol extract prepared from fruit bodies of $M$. lobayensis. Further, the fraction was evaluated for putative therapeutic abilities namely antioxidant, antibacterial and cytotoxic effects to predict usefulness of the edible mushroom as a functional food ingredient.

\section{MATERIALS AND METHODS}

\section{Standards and reagents}

Ferrozine, ferrous chloride, potassium ferricyanide, ferric chloride, 2,2-Diphenyl-1-picrylhydrazyl (DPPH), sodium persulfate, ammonium molybdate, 2'-azinobis (3ethylbenzothiazoline-6-sulfonic acid) (ABTS), Folin-Ciocalteu reagent, 2,6-dichlorophenol indophenol (DCPIP), ascorbic acid, ethylene diaminetetraacetic acid (EDTA), gallic acid, quercetin, oxalic acid, nutrient broth (NB), $p$-iodonitrotetrazolium chloride (INT) and Dulbecco's Modified Eagles Medium (DMEM) were purchased from Himedia, Mumbai, India. Eleven HPLC standards such as gallic acid, $p$-hydroxybenzoic acid, chlorogenic acid, vanillic acid, $p$-coumaric acid, ferulic acid, myricetin, salicylic acid, quercetin, cinnamic acid and pyrogallol were used from Sigma Aldrich (MO, USA). Water-soluble tetrazolium (WST) and fetal bovine serum (FBS) were procured from Takara Bio Inc, Japan and Invitrogen, Carlsbad, CA, USA respectively. PenStrep and amphotericin B were purchased from MP Biomedicals, Santa Ana, CA, USA.

\section{Mushroom collection and authentication}

Fresh basidiocarps of $M$. lobayensis $(\sim 50 \mathrm{~g})$ were assembled from their natural habitat at coastal area of West Bengal, India during the month of August, 2014 and identified using standard literature (Pegler et al., 1998). A voucher specimen was deposited in the same department with accession number of CUH AM483 following the method of Pradhan et al. (2015). Fruit bodies were dried by a field drier at $40{ }^{\circ} \mathrm{C}$ to make them crispy. Dried basidiocarps were pulverized using electric blender, sieved through 160 mesh and preserved in air tight container.

\section{Preparation of crude methanol extract}

Ten $\mathrm{g}$ of dried and powdered fruit bodies were steeped in $200 \mathrm{ml}$ methanol for two days and filtered residue was re-extracted with methanol. The combined fraction was evaporated at $40^{\circ} \mathrm{C}$ under reduced pressure (Rotavapor R-3, Butchi, Switzerland) to acquire methanol extract of $M$. lobayensis. The yield percentage was calculated based on dry weight:

$$
\text { Yield }(\%)=\left(\mathrm{W}_{1} \times 100\right) / \mathrm{W}_{2}
$$

Where $\mathrm{W}_{1}=$ weight of extract after solvent evaporation; $\mathrm{W}_{2}=$ weight of the minced mushroom 


\section{Total polyphenol content determination}

To determine total phenolic compounds $1 \mathrm{ml}$ of the methanol extract was mixed with $1 \mathrm{ml}$ of Folin-Ciocalteu reagent. After 3 min incubation, $1 \mathrm{ml}$ sodium carbonate solution (35\%) was added and adjusted to $10 \mathrm{ml}$ by water. The reaction was kept in dark for $90 \mathrm{~min}$, and absorbance was measured at $725 \mathrm{~nm}$ against blank. Gallic acid (10-40 $\mu \mathrm{g})$ was considered as standard and results were expressed as $\mu \mathrm{g}$ of gallic acid equivalents per $\mathrm{mg}$ of extract (Khatua et al., 2015).

\section{Total flavonoid estimation}

$1 \mathrm{ml}$ methanol extract was diluted with $4.1 \mathrm{ml}$ of $80 \%$ aqueous ethanol, $0.1 \mathrm{ml}$ of $1 \mathrm{M}$ potassium acetate and $0.1 \mathrm{ml}$ of $10 \%$ aluminium nitrate to estimate total flavonoid content. After 40 min incubation at room temperature absorbance was detected at $415 \mathrm{~nm}$. Quercetin $(5-20 \mu \mathrm{g})$ was used to calculate the standard curve and results were expressed as $\mu \mathrm{g}$ of quercetin equivalents per mg of extract (Khatua et al., 2015).

\section{$\beta$-carotene and lycopene estimation}

$100 \mathrm{mg}$ methanol fraction was mixed with $10 \mathrm{ml}$ acetone-hexane solution (4:6) and filtered through Whatman no 4. Absorbance was detected at three different wavelengths simultaneously such as 453, 505, $663 \mathrm{~nm}$ (Khatua et al., 2015). Content of carotenoids were calculated according to the following equations:

$$
\begin{aligned}
& \beta \text {-carotene (mg/100 ml): } 0.216 \mathrm{~A}_{663}-0.304 \mathrm{~A}_{505}+0.452 \mathrm{~A}_{453} \\
& \text { Lycopene (mg/100 ml): }-0.0458 \mathrm{~A}_{663}+0.372 \mathrm{~A}_{505}-0.0806 \mathrm{~A}_{453}
\end{aligned}
$$

\section{Ascorbic acid determination}

$10 \mathrm{ml}$ ascorbic acid $(100 \mu \mathrm{g} / \mathrm{ml})$ was prepared using $0.6 \%$ oxalic acid and titrated against 2,6-dichlorophenol indophenol dye. The extent of dye consumed $\left(\mathrm{V}_{1} \mathrm{ml}\right)$ represented the quantity of ascorbic acid. Likewise, sample (concentration W $\mu \mathrm{g} / \mathrm{ml})$ was also titrated against dye $\left(\mathrm{V}_{2} \mathrm{ml}\right)$ (Khatua et al., 2015) and amount of ascorbic acid present in the fraction was calculated using following formula,

Ascorbic acid $(\mu \mathrm{g} / \mathrm{mg})=\left[\left\{\left(10 \mu \mathrm{g} / \mathrm{V}_{1} \mathrm{ml}\right) \times \mathrm{V}_{2} \mathrm{ml}\right\} \times \mathrm{W} \mu \mathrm{g}\right] \times 1000$

\section{Quantification of phenolic compounds by HPLC}

$10 \mathrm{mg}$ dried extract was dissolved in $1 \mathrm{ml}$ of HPLC grade methanol and filtered through $0.2 \mu \mathrm{m}$ filter paper. $20 \mu \mathrm{l}$ filtrate was loaded on the HPLC system (Agilent, USA) and separation was achieved on Agilent Eclipse Plus C18 column $(100 \mathrm{~mm} \times 4.6 \mathrm{~mm}$, $3.5 \mu \mathrm{m}$ ) using a flow rate of $0.8 \mathrm{ml} / \mathrm{min}$ at $25^{\circ} \mathrm{C}$. The mobile phase consisted of eluent A (acetonitrile) and eluent B (aqueous phosphoric acid solution, $0.1 \% \mathrm{v} / \mathrm{v})$. A gradient program was used for elution: 0-2 min, 5\% A; 5-10 min, $15 \%$ A; $10-15 \min , 40 \%$ A; 15-20 min, $60 \%$ A; $20-22 \mathrm{~min}, 90 \% \mathrm{~A}$. The absorbance of standard and sample solution was measured at $280 \mathrm{~nm}$ (Chatterjee et al., 2016). Sample compounds were identified on the basis of retention times and absorption spectra of standard materials.
Components were quantized by comparing their peak areas with those of standard curves.

\section{Determination of total antioxidant capacity by phosphomolybdenum method}

The reaction mixture consisted of $3 \mathrm{ml}$ of reagent solution ( $0.6 \mathrm{M}$ sulphuric acid, $28 \mathrm{mM}$ sodium sulphate and $4 \mathrm{mM}$ ammonium molybdate) and $0.3 \mathrm{ml}$ sample solution. The resultant solution was incubated at $95^{\circ} \mathrm{C}$ for $90 \mathrm{~min}$ and absorbance was measured at $695 \mathrm{~nm}$ against blank. Concentrations of ascorbic acid $(1-30 \mu \mathrm{g})$ were plotted to obtain a standard curve. Total antioxidant activity was expressed as the number of equivalents of ascorbic acid (Prieto et al., 1999).

\section{DPPH radical scavenging assay}

To determine DPPH radical scavenging activity, methanol extract at various concentration $(100-1000 \mu \mathrm{g} / \mathrm{ml})$ was mixed with $0.004 \%$ DPPH solution in a reaction mixture of $200 \mu \mathrm{l}$ in 96 well microtiter plate. The plate was incubated for $30 \mathrm{~min}$ in dark followed by detection of final colour at $595 \mathrm{~nm}$ using microplate reader (Bio-Rad iMarkTM Microplate Reader, USA) (Khatua et al., 2017b).

\section{ABTS radical scavenging assay}

Extent of radical quenching potentiality of the fraction was again tested by using ABTS. Accordingly, radicals were generated freshly by adding $2.45 \mathrm{mM}$ of potassium persulfate in 7 $\mathrm{mM}$ ABTS solution and the mixture was incubated overnight. Further, the reactant was diluted to 0.7 absorbance and radicals were allowed to react with methanol extract at variable doses (100$1000 \mu \mathrm{g} / \mathrm{ml})$ in $200 \mu \mathrm{l}$ reaction mixture in 96 well plate. The plate was shaken for 10 seconds at medium speed and absorbance was noticed at $750 \mathrm{~nm}$ (Khatua et al., 2017b).

\section{Chelating ability of ferrous ion}

In addition, the assay of chelating ability of ferrous ion was also followed; hence $5 \mu \mathrm{l}$ ferrous chloride $(3 \mathrm{nM})$ was mixed with methanol formulation at different level $(100-1000 \mu \mathrm{g} / \mathrm{ml})$. Then, $10 \mu \mathrm{l}$ ferrozine $(0.12 \mathrm{nM})$ was added and absorbance was estimated at $595 \mathrm{~nm}$ following incubation for $10 \mathrm{~min}$ using microplate reader (Khatua et al., 2017b).

\section{Determination of reducing power}

Further to that, reducing power of the examined fraction was evaluated by mixing $10 \mu \mathrm{l}$ of extract solution containing a range of concentrations $(500-2500 \mu \mathrm{g} / \mathrm{ml})$ with $25 \mu \mathrm{l}$ sodium phosphate buffer and $25 \mu \mathrm{l}$ potassium ferricyanide $(1 \%)$ in 96 well plate. After incubation for 20 minutes, $85 \mu \mathrm{l}$ water and $8.5 \mu \mathrm{l}$ ferric chloride were added in each well separately. Finally, the optical density was determined at $750 \mathrm{~nm}$ using same microplate reader as mentioned earlier (Khatua et al., 2017b).

To compare the effects of extract with a standard, ascorbic acid was used in all assays except chelating ability of ferrous ion method where EDTA was adopted as a positive 
control. The sample concentration exhibiting $50 \%$ of antioxidant activity or 0.5 of absorbance were determined from graphs of antioxidant activity percentages and regarded as $\mathrm{EC}_{50}$ value.

\section{Estimation of antibacterial potentiality}

Bacillus subtilis ATCC ${ }^{\circledR}$ 6633 ${ }^{\mathrm{TM}}$ (MTCC 736), Listeria monocytogenes ATCC ${ }^{\circledR} 19111^{\mathrm{TM}}$ (MTCC 657), Staphylococcus aureus ATCC $^{\circledR} 700699^{\mathrm{TM}}$, Escherichia coli ATCC $^{\circledR} 25922^{\mathrm{TM}}$ and Salmonella typhimurium ATCC ${ }^{\circledR} 23564^{\mathrm{TM}}$ (MTCC 98), Klebsiella pneumoniae $\mathrm{ATCC}^{\circledR} 15380^{\mathrm{TM}}$ (MTCC 109) were utilized for the experiment. Antibacterial effect was estimated by determining MIC values according to microdilution method (Khatua et al., 2017a).

The six investigating bacteria were cultured freshly and $1 \times 10^{5} \mathrm{CFU} / \mathrm{ml}$ concentrated dilutions were prepared separately. Reactions were performed in 96 well plate consisting of $200 \mu \mathrm{l}$ of NB, $20 \mu \mathrm{l}$ of inoculum and different dilutions of methanol extract. Following incubation for $24 \mathrm{~h}$ at $37^{\circ} \mathrm{C}, 40 \mu \mathrm{l}$ of INT dye $(0.2$ $\mathrm{mg} / \mathrm{ml}$ ) was added to each well and incubated for another $30 \mathrm{~min}$. Concentration that inhibited $50 \%$ growth of bacteria in comparison with positive control was calculated as MIC value. Streptomycin was used as a standard drug.

\section{Estimation of cytotoxic activity}

Hep3B human liver cancer cell line was purchased from NCCS, Pune, India. The cells were maintained in DMEM supplemented with $10 \%$ FBS, $0.5 \%$ PenStrep $(5,000 \mathrm{IU} / \mathrm{ml}$ penicillin and $5 \mathrm{mg} / \mathrm{ml}$ streptomycin) and $0.25 \%$ amphotericin $\mathrm{B}$ $(250 \mu \mathrm{g} / \mathrm{ml})$ at $37^{\circ} \mathrm{C}$ in a humidified atmosphere with $5 \% \mathrm{CO}_{2}$. Inhibition of cell viability was determined using WST assay. Briefly, about $1 \times 10^{4}$ cells were seeded in 96-well plate before methanolic extract dissolved in sterile DMSO was added. $20 \mu \mathrm{l}$ WST reagent was added after $48 \mathrm{~h}$ treatment and absorbance was measured using ELISA plate reader at a wavelength of $450 \mathrm{~nm}$.

\section{Statistical analysis}

All data are presented herein as mean \pm standard deviation of three independent experiments each in triplicate. Calculations were performed using statistical package for Microsoft ${ }^{\circledR}$ Office Excel (Microsoft ${ }^{\circledR}$, USA) and differences were evaluated by means of one-way analysis of variance (ANOVA).

\section{RESULTS AND DISCUSSION}

\section{Recovery percentage and mycochemical analysis}

In last decades, extensive studies have been conducted on mushrooms with an aim to isolate and identify bioactive compounds. Thus, selection of extraction solvent is a key step to explore the field as it has direct effect on concentration and type of bioactive compounds.

In that view, aqueous condition is widely used for screening pharmacological potential of macrofungi. However, organic compounds specifically phenolic constituents are mainly recognized as active therapeutics and they could easily be obtained through methanol extraction process (Matijašević et al., 2016). Likewise, methanol was used in the present study for preliminary investigation on bio-organic components of $M$. lobayensis entailing medicinal effects.

As depicted in Table 1, the formulation had high recovery percentage and that could be attributed to different types of constituents extracted in appreciable amount. Briefly, phenols were determined as the major component which was present two times higher than flavonoids. In contrary, carotenoids like $\beta$ carotene and lycopene were detected in the lowest extent and existed about ten times less than ascorbic acid. Thus, it could be said that the elements were present quantitatively in the following order of phenol> flavonoid> ascorbic acid> carotenoids. The finding was detected to be in accordance with previous publication (Acharya et al., 2017a).

Table 1: Extractive yield and mycochemical analysis of methanol extract prepared from fruit bodies of Macrocybe lobayensis. ND: Not detected
Parameters

Extractive yield (\%)

Phenol ( $\mu \mathrm{g} \mathrm{GAE} / \mathrm{mg}$ of extract)

Flavonoid ( $\mu \mathrm{g} \mathrm{QE} / \mathrm{mg}$ of extract)

$\beta$-carotene $(\mu \mathrm{g} / \mathrm{mg}$ of extract)

Lycopene $(\mu \mathrm{g} / \mathrm{mg}$ of extract)

Ascorbic acid $(\mu \mathrm{g} / \mathrm{mg}$ of extract)

Gallic acid ( $\mu \mathrm{g} / \mathrm{mg}$ of extract)

$p$-hydroxybenzoic acid ( $\mu \mathrm{g} / \mathrm{mg}$ of extract)

Chlorogenic acid $(\mu \mathrm{g} / \mathrm{mg}$ of extract)

Vanillic acid ( $\mu \mathrm{g} / \mathrm{mg}$ of extract)

$p$-coumaric acid $(\mu \mathrm{g} / \mathrm{mg}$ of extract)

Ferulic acid $(\mu \mathrm{g} / \mathrm{mg}$ of extract)

Myricetin ( $\mu \mathrm{g} / \mathrm{mg}$ of extract)

Salicylic acid $(\mu \mathrm{g} / \mathrm{mg}$ of extract)

Quercetin ( $\mu \mathrm{g} / \mathrm{mg}$ of extract)

Cinnamic acid ( $\mu \mathrm{g} / \mathrm{mg}$ of extract)

Pyrogallol ( $\mu \mathrm{g} / \mathrm{mg}$ of extract)
Methanol extract

$16 \pm 0.29$

$10.96 \pm 0.11$

$5.12 \pm 1.51$

$0.29 \pm 0.07$

$0.20 \pm 0.05$

$2.22 \pm 0.28$

ND

$0.04 \pm 0$

ND

ND

$0.06 \pm 0$

ND

ND

$0.26 \pm 0.01$

ND

$0.19 \pm 0.01$

$8.04 \pm 2.9$
Further to that, HPLC profile of the fraction was recorded to provide a phenolic fingerprint and identify major molecular components (Figure 1). The chromatogram depicted that at least 11 components were present in the extract of which five were tentatively recognized and quantified (Table 1). Briefly, $p$ hydroxybenzoic acid, $p$-coumaric acid, salicylic acid, cinnamic acid and pyrogallol were positively ascertained according to their retention time as well as UV spectrum characteristics comparable with commercial standards. Among them, pyrogallol was noted as the major constituent and presented approximately eight times higher than salicylic acid, the second most abundant organic component in the formulation.

In contrary, cinnamic acid, $p$-coumaric acid and $p$ hydroxybenzoic acid were detected in vestigial amounts. Surprisingly, pyrogallol, cinnamic acid and $p$-hydroxybenzoic acid have also been detected in methanol extract of other Macrocybe sp. namely M. crassa and M. gigantea (Khatua and Acharya 2014, Chatterjee et al 2016); hence these hydroxybenzoic acid derivatives might be regarded as the most frequently found phenolic component in Macrocybe members. 


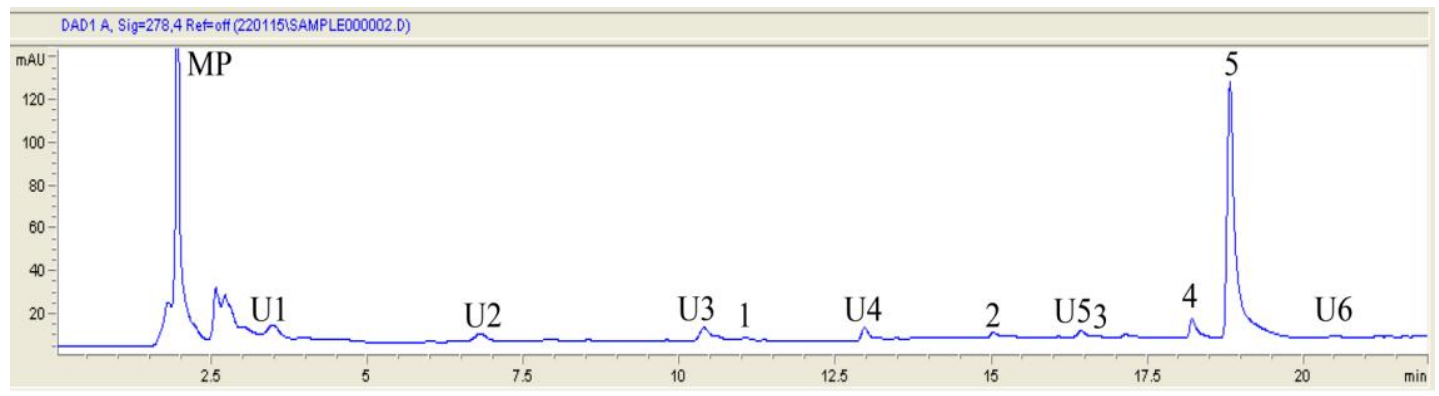

Fig. 1: HPLC chromatogram of methanol extract isolated from Macrocybe lobayensis (MP: mobile phase, peaks 1: $p$ hydroxybenzoic acid (Rt $11.05 \mathrm{~min}$ ), 2: p-coumaric acid (Rt $15.02 \mathrm{~min}$ ), 3: salicylic acid (Rt $17.14 \mathrm{~min}$ ) 4: cinnamic acid (Rt $18.22 \mathrm{~min}$ ) 5: pyrogallol (Rt $18.82 \mathrm{~min}$ ). Peaks designated as U1 to U6 represent unidentified phenols that were eluted at retention time of $3.47 \mathrm{~min}, 6.8 \mathrm{~min}, 10.38 \mathrm{~min}, 12.96 \mathrm{~min}, 16.43 \mathrm{~min}$ and $20.47 \mathrm{~min}$ respectively.

Table 2: Antioxidant activity of methanol extract isolated from Macrocybe lobayensis. The results are presented in $\mathrm{EC}_{50}$ values (mean \pm standard deviation; $\mathrm{n}=3$ ) corresponding to $50 \%$ of antioxidant activity or 0.5 of absorbance for reducing power assay. Ascorbic acid was used as standard in DPPH and ABTS radical scavenging methods, reducing power and total antioxidant capacity assays; while EDTA was adopted as a positive control in chelating ability of ferrous ion technique. In each row, different letters mean significant differences between sample and standard $(p<0.05)$.

\begin{tabular}{|c|c|c|c|}
\hline & Antioxidant parameters & Methanol extract & Standard \\
\hline \multirow{4}{*}{$\begin{array}{l}\mathrm{EC}_{50} \text { value } \\
(\mu \mathrm{g} / \mathrm{ml})\end{array}$} & Scavenging ability of DPPH radical & $610.93 \pm 10.66^{\mathrm{a}}$ & $7.69 \pm 0.02^{b}$ \\
\hline & Scavenging ability of ABTS radical & $659.94 \pm 1.12^{\mathrm{a}}$ & $3.18 \pm 0.01^{\mathrm{b}}$ \\
\hline & Reducing power & $1785.83 \pm 319.16^{\mathrm{a}}$ & $18.74 \pm 0.01^{\mathrm{b}}$ \\
\hline & Chelating ability of ferrous ion & $990.5 \pm 30.3^{\mathrm{a}}$ & $11.81 \pm 0.58^{\mathrm{b}}$ \\
\hline \multicolumn{2}{|c|}{$\begin{array}{c}\text { Total antioxidant activity by phosphomolybdenum method ( } \mu \mathrm{g} \text { ascorbic acid } \\
\text { equivalent/mg of dry extract) }\end{array}$} & $19.35 \pm 0.14$ & - \\
\hline
\end{tabular}

\section{Evaluation of antioxidant activity}

In the present study, five in vitro methods were performed in order to evaluate antioxidant ability of methanol extract from $M$. lobyensis and the effects have been depicted in Table 2. Initially, total antioxidant activity of extract was determined by following phospho-molybdenum method and the activity was compared with a positive control, ascorbic acid. Principle of the technique was based on reducing ability of antioxidant compounds to form Mo (V) from Mo (VI) that eventually generates green colored phosphate/Mo (V) complex. According to the result, reducing capacity of $1 \mathrm{mg}$ of studied methanol fraction was equivalent to $19.35 \mu \mathrm{g}$ ascorbic acid.

DPPH is a commercially available stable organic nitrogen radical and accepts an electron or hydrogen to become stable diamagnetic radical. The advantage of this assay is that DPPH does not have to be generated before the assay, in contrast to other scavenging methods. The radical can be neutralized by antioxidants as they have ability to donate electron without being free radical itself ( $\mathrm{Lü}$ et al., 2010). Thus, the degree of DPPH scavenging can be used to magnitude hydrogen donating ability of antioxidants. Hence, DPPH radical scavenging model was implemented herein to evaluate antioxidant potentiality of the natural compound. Method was based on reduction of the radical to DPPH-H in presence of proton-donating element resulting reduction in absorbance from purple to yellow coloured reaction mixture. Thus a lower absorbance at $517 \mathrm{~nm}$ indicates higher radical scavenging activity of extract (Kedare and Singh 2011). Eventually, the methanol extract from M. lobayensis displayed a significant dose dependent scavenging pattern at the tested concentration ranges and results were plotted in Figure 2A. At the level of 100,500 and $1000 \mu \mathrm{g} / \mathrm{ml}$ of extract the inhibition rates were $16.55 \%, 44.01 \%$ and $76.07 \%$ respectively demonstrating high scavenging abilities. In this experiment, ascorbic acid was used as a positive control for comparison which exhibited much powerful activity.

Nevertheless, ABTS radical cation was used in the present study for further assessment of antioxidant activity of methanol extract. In this method, ABTS $^{-}$were generated by persulfate oxidation of $\mathrm{ABTS}^{2-}$ and neutralized in presence of antioxidant component resulting decolourization (Huang et al., 2005). Analysis showed that the fraction possessed strong radical scavenging capacity that incremented in a dose-dependent manner (Figure 2B). As the concentration ranged from 100, 500 to 1000 $\mu \mathrm{g} / \mathrm{ml}$, inhibition activities of the formulation amplified from $23.92 \%, 36.18 \%$ to $79.46 \%$. However, the synthetic antioxidant, ascorbic acid, exhibited about $99 \%$ radical quenching activities at those tested concentrations and thus proved to be an excellent scavenger.

Ferrous ions can act as catalysts in formation of hydroxyl, peroxyl and alkoxyl radicals. Chelating agent stabilizes this transition metal and reduces damage caused by free radicals. So moderate ferrous ion chelating abilities would be beneficial to protect human beings (Lü et al., 2010). In this assay, ferrozine forms complexes with $\mathrm{Fe}^{2+}$ resulting in violet colour. In presence of chelating agent, the complex formation is disrupted, thus colour intensity reduces. Reduction therefore allows estimation of chelating ability of coexisting chelator. 


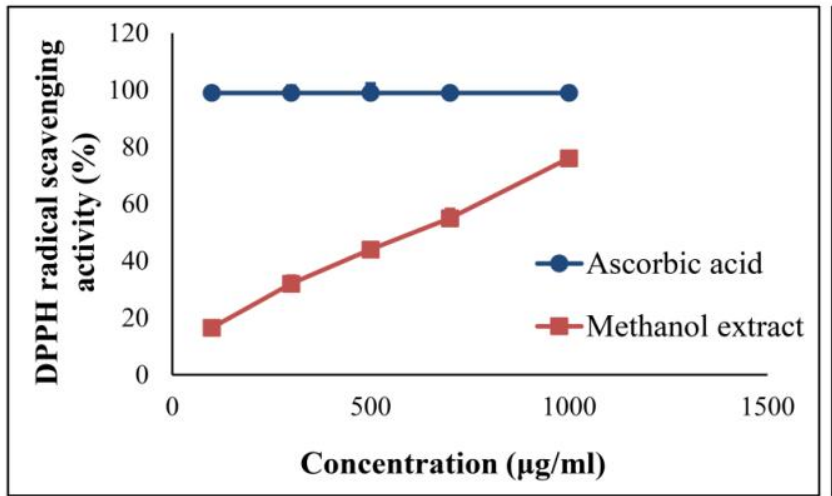

A

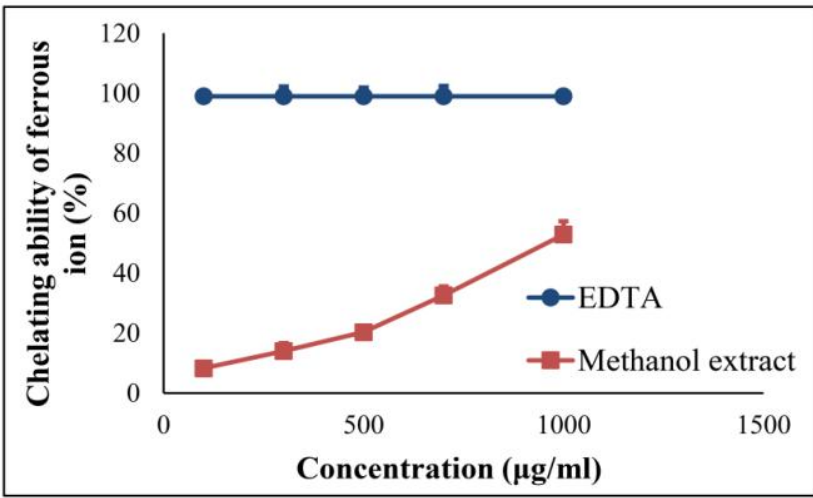

C
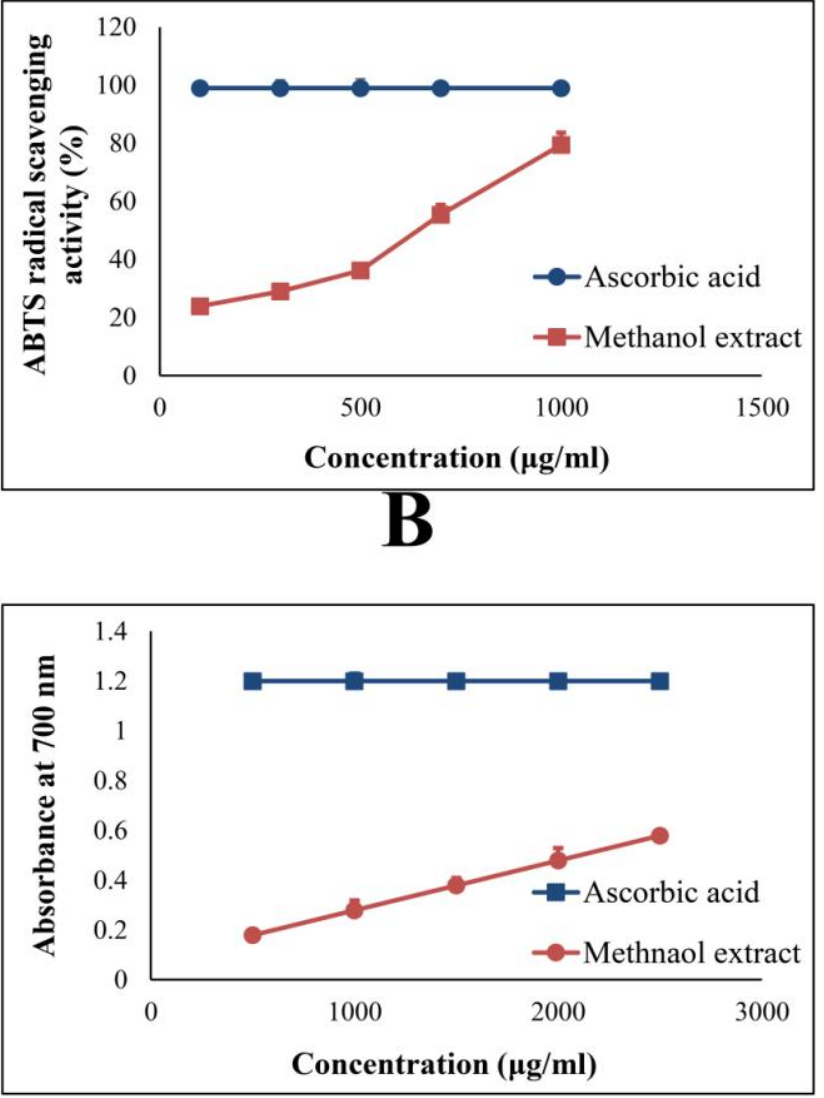

D

Fig. 2: Antioxidant activity of methanol extract prepared from Macrocybe lobayensis (A) DPPH radical scavenging activity (B) ABTS radical scavenging activity (C) Chelating ability of ferrous ion (D) Reducing power. Results represent mean \pm standard deviation of at least three independent experiments.

Figure $2 \mathrm{C}$ revealed that at the concentration of 100, 500 and $1000 \mu \mathrm{g} / \mathrm{ml}$ the extract was able to chelate $8.29 \%, 20.3 \%$ and $52.88 \%$ ferrous ions respectively whereas EDTA chelated $>95 \%$ at these same concentration.

Finally, the ferricyanide/prussian blue assay was carried out to determine reducing power of methanol extract. The method was based on action of electron-donating antioxidants to reduce yellow ferric form to blue ferrous form. However, the reducing ability of a sample is not directly correlated to its radical scavenging activity but it is considered as an important parameter of antioxidants (Huang et al., 2005). According to results, the fraction exhibited moderate reducing power which incremented with rise of concentration. At level of 1500 and $2000 \mu \mathrm{g} / \mathrm{ml}$ concentration reducing power of the formulation were 0.34 and 0.48 that gradually elevated to 0.58 at the dose of $2500 \mu \mathrm{g} / \mathrm{ml}$ (Figure 2D). In the present assay, ascorbic acid was selected as a standard for comparison and it exhibited obvious superior antioxidant potentiality.

In the last decade, several reports have been published regarding antioxidant activity of methanol fraction extracted from mushroom. Based on the outcome, it can be said that $M$. lobayensis may possess stronger radical scavenging and total antioxidant potentiality than methanol extract isolated from
M. crassa (Khatua and Acharya 2014), Pleurotus djamor (Acharya et al., 2017b) and Grifola frondosa (Acharya et al., 2015a). The data also implied that fraction exhibited enhanced reducing power than Ramaria flava, Rhizopogon roseolus and Russula delica (Gursoy et al., 2010). In contrary, the fraction exhibited less effective antioxidant activities than methanolic extract prepared from Laetiporus sulphureus (Acharya et al., 2016) and Ramaria subalpina (Acharya et al., 2017a). Overall, it can be conferred that the fraction owns relatively strong antioxidant ability as reflected in all aforementioned assays and can therefore be used as a potent antioxidant.

\section{Evaluation of antibacterial activity}

Activity of the methanol extract from M. lobayensis was tested against some pathogenic bacteria by microdilution method where streptomycin was considered as a standard drug for comparison. The fraction was found to be active against all the examined Gram positive and Gram negative species (Table 3). The MIC values obtained indicated that the most susceptible bacterium was $L$. monocytogenes, followed by $S$. aureus while $K$. pneumoniae showed the least sensitivity. The result was in accordance with previous reports that, generally, Gram positive bacteria are considered more sensitive to different compounds. 
Gram negative organisms are difficult to be inhibited because of structure of their cell walls (Khatua et al., 2017a). Further to that, the fraction exhibited low activities in comparison with streptomycin towards all the investigating microorganisms. However, the potentiality of studied fraction was found to be more effective than methanol extract of Amanita rubescens, Cantharellus cibarius, Lactarius piperatus, Russula cyanoxantha (Kosanic et al., 2013), Lycoperdon perlatum, Clavaria vermiculris, Ramaria formosa, Marasmius oreades and Pleurotus pulmonarius (Ramesh and Pattar 2010).

Table 3: Antibacterial activity of methanol extract isolated from Macrocybe lobayensis as determined by minimum inhibitory concentration (MIC). Each value is expressed as mean \pm standard deviation $(n=3)$. In each row, different letters mean significant differences between sample and standard $(p<0.05)$.

\begin{tabular}{cccc}
\hline \multirow{2}{*}{$\begin{array}{c}\text { Type of } \\
\text { bacteria }\end{array}$} & Name of bacteria & \multicolumn{2}{c}{ MIC value $(\boldsymbol{\mu} \mathbf{g} / \mathbf{m l})$} \\
\cline { 2 - 4 } & & Methanol extract & Streptomycin \\
\hline \multirow{2}{*}{$\begin{array}{c}\text { Gram } \\
\text { positive }\end{array}$} & Listeria monocytogenes & $245.13 \pm 26.1^{\mathrm{a}}$ & $4.68 \pm 0.17^{\mathrm{b}}$ \\
\cline { 2 - 4 } & Bacillus subtilis & $311.29 \pm 43.54^{\mathrm{a}}$ & $5.61 \pm 0.01^{\mathrm{b}}$ \\
\cline { 2 - 4 } & Staphylococcus aureus & $309.3 \pm 11.21^{\mathrm{a}}$ & $6.29 \pm 0.16^{\mathrm{b}}$ \\
\cline { 2 - 4 } $\begin{array}{c}\text { Gram } \\
\text { negative }\end{array}$ & Elebsiella pneumoniae & $659.5 \pm 29^{\mathrm{a}}$ & $5.41 \pm 0.11^{\mathrm{b}}$ \\
\cline { 2 - 4 } & Salmonella typhimurium & $1238.66 \pm 115.67^{\mathrm{a}}$ & $5.09 \pm 0.03^{\mathrm{b}}$ \\
\hline
\end{tabular}

So far, many phenolic compounds isolated from mushrooms have been detected to be responsible for diverse biological activities, including antimicrobial effects. For phenolic compounds, it was evidenced that the number and site(s) of hydroxyl groups determines their toxic effect to microorganisms which is possibly executed by enzyme inhibition. Further, the other secondary metabolites, for instance flavonoids, are proposed to act against microbial infections by inhibiting cell membrane, cell wall and nucleic acid synthesis along with energy metabolism (Matijašević et al., 2016). On the other hand, the mode of action of alcohols and terpenes involves disruption of microbial membranes. Thus, it could be assumed that the antibacterial activity of $M$. lobayensis would be related to its mycochemicals particularly phenolic components.

\section{Estimation of cytotoxic activity}

To study the growth inhibitory activity in vitro, Hep3B cells were incubated for $48 \mathrm{~h}$ with varied doses of methanol extract from $M$. lobayensis. Potential toxic effect of the fraction was evaluated using WST assay based on generation of orange coloured formazan dye in direct proportional to number of living cells. Result showed that the percentage of inhibition was 2.77, $24.74,68.25$ and 70.15 when the concentration was 50, 100, 300 and $500 \mu \mathrm{g} / \mathrm{ml}$ respectively (Figure 3). Thus, the formulation displayed effective growth inhibitory activity on the human liver cancer cell line with $\mathrm{IC}_{50} 234.31 \pm 7.96 \mu \mathrm{g} / \mathrm{ml}$.

Generally, fungal anticancer substances can be divided into two major groups such as high and low molecular weight components. Polysaccharides and protein-bound polysaccharides comprise most of the high molecular weight compounds; whilst phenolics, steroids, sesquiterpenes, triterpenes, sterols and polyketides form the second group. These low molecular wight ingredients are able to penetrate cell membrane and function on specific signal transduction cascade (Liu et al., 2013). As a result, discovery of new molecules extracted by organic solvent from higher basidiomycetous members is a global trending currently. For instance, anticancer activity of methanol, ethanol and boiled water extract from Suillus collinitus was investigated on several human cancer cell lines where the methanolic fraction was found to be the most effective (Vaz et al., 2012). On the other hand, methanol formulation of Antrodia cinnamomea exhibited high hepatocellular activity with $\mathrm{IC}_{50}$ value of $<150 \mu \mathrm{g} / \mathrm{ml}$; though hot water fraction prepared from the same mushroom did not show promising activity even after treatment of $48 \mathrm{~h}$ (Cha et al., 2009).

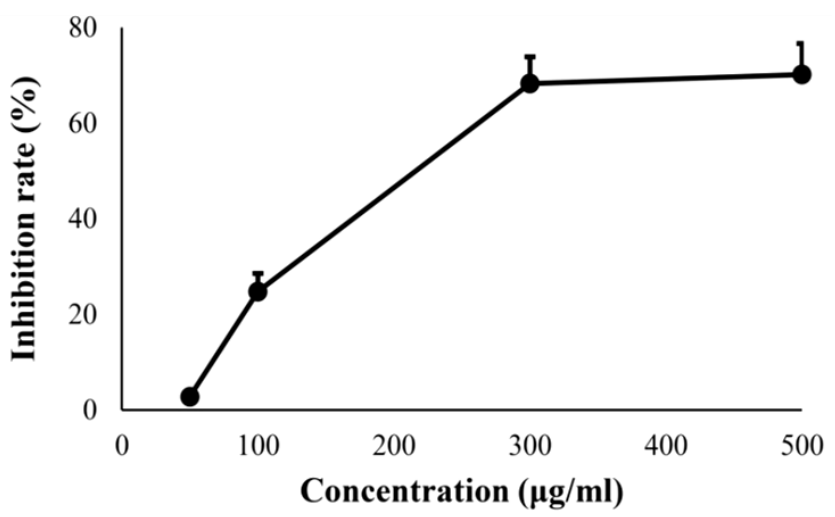

Fig 3: Cytotoxic effect of methanol extract from Macrocybe lobayensis: Hep3B human liver cancer cells were treated with various concentrations of the fraction for $48 \mathrm{~h}$ and the cell growth inhibition was quantified by WST assay.

\section{CONCLUSION}

In conclusion, methanol extract from $M$. lobayensis could be considered as a potential source of biomedicine with respect to antioxidant, antibacterial and cytotoxic effects. These putative therapeutic abilities might be attributed to phenols and flavonoids as they were present predominantly in the fraction. However, isolation and evaluation on key component(s) that has the direct effect on medicinal prospects need to be elucidated further; such studies may lead to potential discovery of novel, natural and bioactive drugs.

\section{ACKNOWLEDGMENT}

Financial support and sponsorship: Authors are thankful to DST, FIST, Govt. of India for providing financial support of instruments.

Conflict of Interests: There are no conflicts of interest.

\section{REFERENCES}

Acharya K, Bera I, Khatua S, Rai M. Pharmacognostic standardization of Grifola frondosa: A well-studied medicinal mushroom. Der Pharmacia Lettre, 2015; 7(7):72-78.

Acharya K, Das K, Paloi S, Dutta AK, Hembrom ME, Khatua S, Parihar A. Exploring a new edible mushroom Ramaria subalpina: Chemical characterization and antioxidant activity. Phcog J, 2017; 9(1): 30-34. 
Acharya K, Ghosh S, Khatua S, Mitra P. Pharmacognostic standardization and antioxidant potentiality of an edible mushroom, Laetiporus sulphureus. J Verbrauch Lebensm, 2016; 11(1):33-42.

Acharya K, Khatua S, Ray S. Quality assessment and antioxidant study of Pleurotus djamor (Rumph. ex Fr.) Boedijn. J Appl Pharmaceutic Sci, 2017; 7(6); 105-110.

Acharya K, Khatua S, Sahid S. Pharmacognostic standardization of Macrocybe crassa: an imminent medicinal mushroom. Res J Pharm Technol, 2015; 8(7):860-866.

Alam MN, Bristi N J, Rafiquzzaman M. Review on in vivo and in vitro methods evaluation of antioxidant activity. Saudi Pharm J, 2013; 21:143-152.

Balouiri M, Sadiki M, Ibnsouda SK. Methods for in vitro evaluating antimicrobial activity: A review. J Pharm Anal, 2016; 6:71-79.

Burcu B, Aysel U, Nurdan S. Antimicrobial, antioxidant, antimutagenic activities, and phenoliccompounds of Iris germanica. Ind Crops Prod, 2014; 61: 526-530.

Cha W, Ding J, Choi D. Comparative evaluation of antioxidant, nitrite scavenging, and antitumor effects of Antrodia camphorata extract. Biotechnol. Bioprocess Eng, 2009; 14:232-237.

Chatterjee S, Chatterjee A, Chandra S, Khatua S, Saha GK, Acharya K. Tricholoma giganteum ameliorates benzo[a]pyrene-induced lung cancer in mice. Int J Cur Pharm Sci Rev Res, 2016; 7(5):283-290.

Gursoy N, Sarikurkcu C, Tepe B, Solak MH. Evaluation of antioxidant activities of 3 edible mushrooms: Ramaria flava (Schaef.: Fr.) Quel., Rhizopogon roseolus (Corda) T.M. Fries., and Russula delica Fr. Food Sci Biotechnol, 2010; 19:691-696.

Huang D, Ou B, Prior RL. The chemistry behind antioxidant capacity assays. J Agric Food Chem, 2005; 53:1841-1856.

Kedare SB, Singh RP. Genesis and development of DPPH method of antioxidant assay, J Food Sci Technol, 2011; 48:412-422.

Khatua S, Acharya K. Antioxidant and antimicrobial potentiality of quantitatively analysed ethanol extract from Macrocybe crassa. Int J Pharm Sci Rev Res, 2014; 29(2):53-60.

Khatua S, Dutta AK, Acharya K. Russula senecis: A delicacy among the tribes of West Bengal. Peer J, 2015; 3:e810.

Khatua S, Dutta K, Chandra S, Paloi S, Das K, Acharya K. Introducing a novel mushroom from mycophagy community with emphasis on biomedical potency. PloS ONE, 2017; 12(5):e0178050.

Khatua S, Ghosh S, Acharya K. A simplified method for microtiter based analysis of in vitro antioxidant activity. Asian $\mathrm{J}$ Pharmacol, 2017; 11(2):S327-S335.

Khatua S, Paul S, Acharya K. Mushroom as the potential source of new generation of antioxidant: a review. Res J Pharm Technol, 2013; 6(5):496-505.

Kosanic M, Rankovic B, Dasic M. Antioxidant and antimicrobial properties of mushrooms. Bulg J Agric Sci, 2013; 19(5):040-1046.

Liu F, Ooi V, Liu W, Chang ST. Immunomodulation and antitumor activity of polysaccharide-protein complex from the culture filtrates of a local edible mushroom, Tricholoma lobayense. Gen Pharmacol, 1996; 27: 621-624.

Liu K, Wang J, Zhao L, Wang Q. Anticancer, antioxidant and antibiotic activities of mushroom Ramaria flava. Food Chem Toxicol, 2013; 58: 375-380.

Lü JM, Lin PH, Yao Q, Chen C. Chemical and molecular mechanisms of antioxidants: Experimental approaches and model systems, J Cell Mol Med, 2010; 14:840-860.

Matijašević D, Pantić M, Rašković B, Pavlović V, Duvnjak D, Sknepnek A et al. The antibacterial activity of Coriolus versicolor methanol extract and its effect on ultrastructural changes of Staphylococcus aureus and Salmonella enteritidis. Front Microbiol, 2016: doi: 10.3389/fmicb.2016.01226
Mitra P, Khatua S, Acharya K. Free radical scavenging and NOS activation properties of water soluble crude polysaccharide from Pleurotus ostreatus. Asian J Pharm Clin Res, 2013; 6(3):67-70.

Nandi AK, Samanta S, Maitya S, Sena IK, Khatua S, Devi KSRet al. Antioxidant and immunostimulant $\beta$-glucan from edible mushroom Russula albonigra (Krombh.) Fr., Carbohydr. Polym, 2014; 99: 774-782.

Pegler DN, Lodge DJ, Nakasone KK, The pantropical genus Macrocybe gen. nov, Mycologia, 1998; 90: 494-504.

Pradhan P, Dutta AK, Acharya K. A low cost long term preservation of macromycetes for fungarium. Protocol Exchange, 2015; doi:10.1038/protex.2015.026

Prieto P, Pineda M, Aguilar M. Spectrophotometric quantitation of antioxidant capacity through the formation of phosphomolybdenum complex: specific application to the determination of vitamin E. Anal Biochem, 1999;269:337-334.

Ramesh C, Pattar MG. Antimicrobial properties, antioxidant activity and bioactive compounds from six wild edible mushrooms of western ghats of Karnataka, India. Pharmacogn Res, 2010; 2(2):107-112.

Ren L, Hemar Y, Perera CO, Lewis G, Krissansen GW, Buchanan PK. Antibacterial and antioxidant activities of aqueous extracts of eight edible mushrooms. Bioact Carbo Diet Fibre, 2014; 3:41-51.

Saha S, Khatua S, Paloi S, Acharya K. Antioxidant and nitric oxide synthase activation properties of water soluble polysaccharides from Pleurotus florida. Int J Green Pharm, 2013; 7: 182-188.

Samanta S, Nandi AK, Sen IK, Maity P, Pattanayak M, Devi KSPet al. Studies on antioxidative and immunostimulating fucogalactan of the edible mushroom Macrolepiota dolichaula. Carbohydr Res, 2015; 413(2):22-29.

Shen H, Shao S, Chen J, Zhou T. Antimicrobials from mushrooms for assuring food safety. Compr Rev Food Sci Food Saf, 2017; 16: 316-329.

Shiraha H, Yamamoto K, Namba M. Human hepatocyte carcinogenesis (review). Int J Oncol, 2013; 42: 1133-1138.

Valko M, Leibfritz D, Moncol J, Cronin MTD, Mazur M, Telser $\mathrm{J}$. Free radicals and antioxidants in normal physiological functions and human disease. Int J Biochem Cell Biol, 2007; 39: 44-84.

Valverde ME, Hernández-Pérez T, Paredes-López O. Edible mushrooms: improving human health and promoting quality life. Int $\mathbf{J}$ Microbiol, 2015: Article ID 376387, doi: 10.1155/2015/376387

Vaz JA, Ferreira IC, Tavares C, Almeida GM, Martins A, Helena VM. Suillus collinitus methanolic extract increases p53 expression and causes cell cycle arrest and apoptosis in a breast cancer cell line. Food Chem, 2012; 135(2):596-602.

Vrinda KB, Pradeep CK. Macrocybe lobayensis, an edible mushroom from Western Ghats of Kerala. Mushroom Res, 2006; 15(2): 2006:157-158.

Yaltirak T, Aslim B, Ozturk S, Alli H. Antimicrobial and antioxidant activities of Russula delica Fr. Food Chem Toxicol, 2009;47: 2052-2056.

\section{How to cite this article:}

Khatua S, Ghosh S, Acharya K. Chemical composition and biological activities of methanol extract from Macrocybe lobayensis. J App Pharm Sci, 2017; 7 (10): 144-151. 